\title{
WEL BESCHOUWD
}

\section{De waarde van ons religieus erfgoed}

\author{
Wim van de Donk
}

In deze column laten leden van de kernredactie van Bestuurswetenschappen (of een gastauteur) hun licht schijnen op actuele vraagstukken in beleid en openbaar bestuur.

Kerken en kloosters zijn markante uitingen van religieus leven en religieuze opvattingen. Zij zijn meer dan dat, het zijn gebouwen die, vaak letterlijk en nog pregnanter figuurlijk, in het hart van de samenleving en de mensen staan. Kerken zijn de gebouwen waar mensen trouwden of troost vonden bij een afscheid. Kloosters zijn het huis van een religieuze gemeenschap, verankerd in idealen. Een gemeenschap die zich ten dienste stelde van God en de samenleving. Kerken en kloosters werden daarmee het fysieke waarmerk van de gemeenschap, het dorp of de stad. Simpel gezegd, wat is 's-Hertogenbosch zonder de Sint Jan, Utrecht zonder de Dom en Groningen zonder d'Olle Grieze? Of Deventer zonder de Lebuinuskerk?

Mensen veranderen, de wijze waarop zij religieuze gevoelens ervaren ook. De behoefte aan het delen van momenten van vreugde en verdriet, het gezamenlijk uitdragen van idealen, die blijven. In nieuwe vormen en op andere manieren. Daarmee vervalt de functie van het gebouw maar niet het feit dat die markante gebouwen gewaardeerd worden en geliefd zijn. Mensen willen ze niet kwijt. Dat levert een uitdaging op.

Een monumentale kerk is nu eenmaal niet gebouwd met het A-label energiezuinig of met de richtlijn voor efficiënt ruimtegebruik in het achterhoofd. Die kerk is een gebouw met een geschiedenis en dat religieuze verleden vormt de identiteit van het gebouw. Houdt het gebouw zijn religieuze functie? Zo nee, wat is dan de oplossing? Zo ja, wat is dan aan activiteiten passend? Het zijn vragen die overal gesteld worden, ook in Brabant.

Er is grote creativiteit bij het zoeken naar oplossingen. Er zijn vele oplossingen, maar één ding komt steeds weer naar voren. De samenwerking tussen parochie of kerkbestuur en de inzet van de gemeenschap, gemeente en provincie en investeerder zijn van vitaal belang. Waar de gemeenschap, al of niet gelovig zich inzet, blijft de kerk in het midden staan!

* Deze column is geschreven als woord vooraf bij dit themanummer van Bestuurswetenschappen over religieus erfgoed. 